\title{
Research on Inheritance of Intangible Cultural Heritage between Professional and Non-Professional Groups: A Case Study of China's Kunqu Opera
}

\author{
Run Zhao ${ }^{1}$ \& Yasufumi Uekita ${ }^{2}$ \\ ${ }^{1}$ Doctoral Program in Heritage Studies, University of Tsukuba, Japan \\ ${ }^{2}$ Faculty of Art and Design, University of Tsukuba, Japan \\ Correspondence: Run Zhao, Heritage Studies, University of Tsukuba, Cooperative Research Building A-204, \\ Tennodai 1-1-1, Tsukuba City, 305-8577, Japan. Tel: 080-9878-5237.
}

Received: July 15, 2021

Accepted: October 20, 2021

Online Published: October 23, 2021

doi:10.5539/ach.v13n2p1

URL: https://doi.org/10.5539/ach.v13n2p1

\begin{abstract}
Non-professional groups, consisting of members gathering together out of the same hobby, have long been deemed as auxiliary power in the inheritance of intangible cultural heritage (ICH). Being widely considered as less important than professional groups, non-professional ones seem to mostly function like governments, IGOs, NGOs, among other things, to indirectly help professionals inherit ICH almost by practicing this heritage as a way of dissemination to build a better social environment friendly towards ICH to live well. However, their role in the direct and faithful inheritance of ICH can be underestimated, or even ignored. In this paper, China's Kunqu Opera is taken as an example, one professional group (Shanghai Kunqu Opera Troupe) and one non-professional group (Shanghai Kunqu Study Society) are chosen to do some comparative analyses in pronunciation, melody, literary form of lyrics, and performing scenes of this art. It is concluded that even though not living off this art, non-professional groups could inherit some traditional factors of Kunqu Opera to a larger degree than professional ones, especially in pronunciation and melody. And one major reason can be summarized that non-professional groups, who cherish the art's tradition heavily, don't need to cater to the mass-market and most modern audience, who are highly influenced by modernization and globalization so that they can preserve these traditional factors carefully by studying, practicing as well as imparting them to other amateurs seriously. Thus, paying more attention to their role in the inheritance of ICH is not only sensible but also essential.
\end{abstract}

Keywords: intangible cultural heritage, inheritance, non-professional groups, Kunqu Opera

\section{Introduction}

Especially for highly complicated performing arts, even though professional groups are major intangible cultural heritage (ICH) bearers, the role of non-professional groups in the inheritance of living heritages shouldn't be overlooked. Nevertheless, they haven't attracted enough attention. As a traditional performing art with a history of more than 400 years, China's Kunqu Opera is a kind of comprehensive art with large complexity, which was proclaimed as one of the Masterpieces of the Oral and Intangible Heritage of Humanity in 2001 by UNESCO. In order to safeguard this ancient living heritage nationwide, China's government launched the National Operational Plan for the Program of Rescuing, Protecting and Supporting Kunqu Opera (国家昆曲艺术抢救、保 护和扶持工程实施方案) in 2005, which is also the first national protection policy for this art as the beginning of a string of related ones.

However, after taking an overall view of the entire text of this policy, non-professional-groups-related words couldn't be found, the same as following policies about this art. According to a report conducted in 2016 about Kunqu Opera societies, which are almost run and made up of amateurs who practice this art as interest, in Suzhou City and Beijing City, except societies on campus, most ones have no fixed venues or sufficient funds. What's more, contrary to professional groups' dominance in media coverage, non-professional ones fail to receive adequate media resources ( $\mathrm{Liu}, \mathrm{Li}, \&$ Shang, 2017). Nevertheless, in spite of these disadvantages, Kunqu Opera societies cherish and inherit some ancient traditions of this art largely, and even larger than professional groups.

In this research, one professional group (Shanghai Kunqu Opera Troupe 上海昆剧团) and one non-professional 
group (Shanghai Kunqu Study Society 上海昆曲研习社)'s inheritance of Kunqu Opera will be compared in pronunciation, melody (kunqiang 昆腔), literary form of lyrics (qupai style 曲牌体) and performing scenes of this art. Different from one former research aiming to figure out Kunqu Opera's core factors by comparing two styles of this art developing in divergent social environments, the Chinese mainland and Taiwan (Zhao \& Uekita, 2020), this article chooses two groups of dissimilar professional levels in the same city. In other words, the two groups here are in the same social environment, facing the same social changes.

Additionally, as non-professional groups, which are singing-centered, seldom perform this art on stage and relevant materials are limited, dance will not be analyzed in this paper. Comparison analyses mainly focus on the singing of these two kinds of groups. Several songs from representative group members will be put under observation.

Discussions about the inheritance of Kunqu Opera in these two groups will be conducted in four factors: pronunciation, especially the obedience to the original pronunciation system, a mix of Suzhou dialect and official language with Zhongzhou rhymes (苏州官话中州韵); melody (kunqiang 昆腔), which is believed to have some traditional rules within it; literary form of lyrics (qupai style 曲牌体), whose rules have been summarized in some reference books and performing scenes of this art.

\section{Literature Review}

The role of non-professional groups in the inheritance and protection of ICH hasn't been discussed sufficiently in previous researches. These groups are often deemed as less important supporting characters for ICH.

Yuan (2017) summarized the interference of government, academia, mass media, and other civic organizations in the protection of $\mathrm{ICH}$ and claimed that formal $\mathrm{ICH}$ bearers are the very main part of protecting practices. Meanwhile, as supporters, other participants' involvement is indispensable in concrete practices, since bearers are not as vigorous as before in times of globalization nowadays. Zhu (2007) investigated the present conditions of art education in several of China's colleges and universities, then pointed out that setting up ICH studying groups on campus is advantageous to safeguarding $\mathrm{ICH}$, especially beneficial to the process of integrating traditional ICH into modern society. Zhang (2007) emphasized the importance of cultural space for the protection of ICH, claimed that ICH bearers are the key part of protecting practices but not the whole, bearers have to cooperate with governmental, commercial, and civil organizations to realize effective protection.

Sun (2012) conducted a survey in Suzhou City on varying kinds of Kunqu Opera's protection organizations, including official and civil ones, and concluded that since each organization has its own merits and demerits, they should strengthen mutual collaboration in order to promote the safeguarding of this art. In Sun's study, non-professional groups are a major means to help disseminate this heritage. Tang (2015) completed a general investigation of Kunqu Opera societies around the Chinese mainland currently and declared that since these societies are rich in flexibility, they are effectively helping this art to reach every part and every generation of the country. Wang (2013) reviewed the development of Kunqu Opera from 1912 to 1949 in Tianjin City, where even though professional groups didn't exist Kunqu-Opera-related activities were still frequently held, then indicated that civil societies played a vital role in the friendly-environment-building process.

Former researchers almost define the function of ICH non-professional groups as assistance for professional ones. However, this image could be enriched through deeper study about them, which will be discussed in this article.

\section{Method}

\subsection{Literature Study}

A literature study was conducted from books, journals, video, and audio materials to get basic information about the Shanghai Kunqu Opera Troupe and the Shanghai Kunqu Study Society, mainly aiming to figure out their similarities and differences in pronunciation, melody, literary form of lyrics, and performing scenes of this opera.

What's more, unlike the Shanghai Kunqu Opera Troupe, which has its own formal textbooks like Sulu Music Scripts (粟庐曲谱), Zhenfei Music Scripts (振飞曲谱), 300 Selected Scenes of Kunqu Opera (昆曲精编教材 300 种) and so on, the Shanghai Kunqu Study Society has no commonly used music scripts as members learned this art from respective masters and often adjust their way of singing according to new understandings about Kunqu Opera. Therefore, records, which can be found in the book Collection of China's Opera Music: Jiangsu Province (中国戏曲音乐集成.江苏卷), of a singing version in 1979 from the Shanghai Kunqu Study Society are selected to do the comparison analyses about melody and literary form of lyrics. And the Shanghai Kunqu Opera Troupe's version is from its textbook: Zhenfei Music Scripts (振飞曲谱), which was first published in 1982. 


\subsection{Online Interview}

As the continuing of the Covid-19 pandemic till now, fieldwork has become hard to conduct. Instead, online interviews were held in order to accomplish this research.

Members of the Shanghai Kunqu Opera Troupe and the Shanghai Kunqu Study Society have been interviewed several times through WeChat and Weibo since April this year for the purpose of making clear their views and practices about the inheritance of Kunqu Opera. What's more, professionals affiliated to Kunqu Opera Museum of China (中国昆曲博物馆) and other related researchers were also interviewed through WeChat from January this year to acquire better comprehension about Kunqu Opera's pronunciation, melody, the literary form of lyrics, and performing scenes.

\subsection{Data Analysis}

In order to accurately judge degrees of inherited traditions about pronunciation and melody in these two groups, factor-based quantitative comparison analysis (Zhao \& Uekita, 2020) will be applied in this article, if one group inherits a higher proportion of tradition, this group can be interpreted as more traditional. Two widely used reference books of pronunciation, Yun Xue Li Zhu (韵学网珠) and Qu Yun Yi Tong (曲韵易通) will be consulted to make the relevant judgment. As for the literary form of lyrics and performing scenes, qualitative analysis will be employed mainly.

\section{Comparison of Four Factors between Shanghai Kunqu Opera Troupe and Shanghai Kunqu Study Society}

\subsection{Pronunciation}

Although various dialects are approved in the singing of Kunqu Opera as a result of its wide-spreading from Suzhou area to other parts of China during its long history, its original pronunciation system, a mix of Suzhou dialect and official language with Zhongzhou rhymes (苏州官话中州韵), is still studied and insisted on by some Kunqu Opera practitioners. One major reference book about the ancient phonetic system is Yun Xue Li Zhu (韵学 网珠), which was written in Qing dynasty (1644-1912) by Suzhou local Shen Chenglin (沈乘鹿). What's more, in order to popularize the ancient pronunciation system, a Kunqu Opera researcher, Xiang Yuancun (项远村), wrote a popular version of the former book for modern people to consult, which is called Qu Yun Yi Tong (曲韵 易通) and was first published in 1963. In this research, these two books will be used to judge which group's pronunciation is closer to the original one.

Even though non-professional groups' information is limited, as senior members of the Shanghai Kunqu Study Society often teach this art at Shanghai's universities, and members from Kunqu study societies on campus are keen to record their teachers' singing as well as make it open to the public, some relevant materials are accessible. In this article, an album, consisting of four songs made by members of Shanghai's Fudan University Kunqu Study Society recording the singing of their teacher Liu Xuntu (柳萱图), a late senior member of the Shanghai Kunqu Study Society, will be applied to do the comparison analyses. In this album, there are 8 Chinese characters in three songs that are obviously pronounced different from professional artists in the Shanghai Kunqu Opera Troupe.

Table 1. Eight differently pronounced Chinese characters between Shanghai Kunqu Opera Troupe and Shanghai Kunqu Study Society in three songs and their observance of original sounds

\begin{tabular}{|c|c|c|c|c|}
\hline Chinese Characters & Source (Song) & Original Sounds & Version 1 & Version 2 \\
\hline 茶 & Yi Jiang Feng (一江风) & $/ \mathrm{ts}^{\mathrm{h}} \mathrm{a} /$ & $/ \mathrm{ts}^{\mathrm{h}} \mathrm{a} /$ & $/ \mathrm{ts}^{\mathrm{h}} \mathrm{a} /$ \\
\hline 蓝 & Yi Jiang Feng (一江风) & /lam/ & /lan/ & /lam/ \\
\hline 顿 & Tai Shi Yin (太师引) & /tuo?/ & /tuən/ & /tuo?/ \\
\hline 阱 & Tai Shi Yin (太师引) & $/ \mathrm{ts}^{\mathrm{h}} \mathrm{In} /$ & $/ \mathrm{tcm} /$ & $/ \mathrm{ts}^{\mathrm{h}} \mathrm{Iy} /$ \\
\hline 全 & Tai Shi Yin (太师引) & /ts'hyan/ & $/ t 6^{\mathrm{h}} \mathrm{n} /$ & $/ \mathrm{ts}^{\mathrm{h}} \mathrm{yan} /$ \\
\hline 堪 & Tai Shi Yin (太师引) & $/ \mathrm{k}^{\mathrm{h}} \mathrm{am} /$ & $/ \mathrm{k}^{\mathrm{h}} \mathrm{an} /$ & $/ \mathrm{k}^{\mathrm{h}} \mathrm{am} /$ \\
\hline 暗 & Yan Zi Le (颜子乐) & /am/ & /an/ & /am/ \\
\hline 南 & Yan Zi Le (颜子乐) & /nam/ & /nan/ & /nam/ \\
\hline & \multicolumn{2}{|c|}{ Observance } & $0 \%$ & $100 \%$ \\
\hline
\end{tabular}

Note. Version 1 is from the Shanghai Kunqu Opera Troupe and Version 2 is from the Shanghai Kunqu Study Society. Original Sounds of the eight Chinese characters are collated according to Yun Xue Li Zhu (韵学网珠) and Qu Yun Yi Tong (曲韵易通). “Observance” means the degree of similarity between singers' pronunciation of the eight Chinese characters and the original sounds. Observance $=$ the number of Chinese characters pronounced as original sounds / Eight. The Shanghai Kunqu Opera Troupe's singing of the song Yi Jiang Feng (一江风) 
from the scene Open the Envelope (拆书), a part of the play The Story of the Western Chamber (西楼记), and the song Tai Shi Yin (太师引) from the scene Pretend to Be Jealous (乔醋), a part of the play The Story of the Golden Bird (金雀记), and the song Yan Zi Le (颜子乐) from the scene Picking Up the Painting (拾画), a part of the play Peony Pavilion (牡丹亭) as well as the Shanghai Kunqu Study Society's member, Liu Xuntu (柳萱图)'s album can be separately found on

https://www.bilibili.com/video/BV1Zx411C7fG/?spm_id_from=333.788.b_7265636f5f6c697374.9,

https://www.bilibili.com/video/BV1aa4y1e7jK/?spm_id_from=333.788.recommend_more_video.4,

https://www.bilibili.com/video/BV19s411p7nB?from=search\&seid=5622323048614898244

and https://www.ximalaya.com/xiqu/7247667/.

As Table 1 shows, in the non-professional group, the Shanghai Kunqu Study Society's version, the eight Chinese characters are all pronounced as original sounds. However, in the professional group, the Shanghai Kunqu Opera Troupe's version, every character is pronounced in another way.

Actually, professional groups' pronunciation has been criticized for adjusting to modern Mandarin nowadays for a long time. Partly because of the Chinese mainland's dramatic social change, especially the Cultural Revolution which spanned 10 years from 1966 to 1976, the number of Kunqu Opera's enthusiasts dived to an extremely low level. The former leader and a major artist of the Shanghai Kunqu Opera Troupe, Cai Zhengren (蔡正仁) once quoted a figure in his article that according to incomplete statistics there were less than 300 enthusiasts of Kunqu Opera in Shanghai city in the 1980s (Cai, 1992), which could only fill a small drama theater. In contrast to the decreasing number, Shanghai's population was increasing continuously and reached 11,859,748 in 1982 based on a report of China's sixth national population census (National Bureau of Statistics, 1982). In other words, approximately only one out of 40,000 citizens were Kunqu Opera enthusiasts in Shanghai at that time. And the scene of desolation was highly perceivable in other cities of China as well. Cai also depicted his experience of performing in Dalian city in 1990, part of the audience began to leave the theater when they knew the next program was Kunqu Opera, and the bulk of them already left when Cai and his partners finished their performance.

Therefore, it is understandable that artists may think they have to cater to the modern audience's taste and habits for the survival of this art and themselves. As a result, Kunqu Opera's pronunciation system has been changed, among other things. Here, the eight Chinese characters' pronunciation of artists from the Shanghai Kunqu Opera Troupe will be compared with sounds of modern Mandarin to verify the hypothesis.

Table 2. Comparison of the pronunciation of eight Chinese Characters between Shanghai Kunqu Opera Troupe and Modern Mandarin

\begin{tabular}{|c|c|c|c|}
\hline Chinese Characters & Source (Song) & Modern Mandarin & Version 1 \\
\hline 茶 & Yi Jiang Feng (一江风) & $/ \mathrm{S}^{\mathrm{h}} \mathrm{a} /$ & $/ \mathrm{ts}^{\mathrm{h}} \mathrm{a} /$ \\
\hline 蓝 & Yi Jiang Feng (一江风) & /lan/ & /lan/ \\
\hline 顿 & Tai Shi Yin (太师引) & /tuən/ & /tuən/ \\
\hline 阱 & Tai Shi Yin (太师引) & $/ \mathrm{t} 6 \mathrm{Iy} /$ & $/ \mathrm{tery} /$ \\
\hline 全 & Tai Shi Yin (太师引) & $/ \mathrm{t} 6^{\mathrm{h}} \mathrm{\wp} /$ & $/ \mathrm{t} 6^{\mathrm{h}} \mathrm{n} /$ \\
\hline 堪 & Tai Shi Yin (太师引) & $/ \mathrm{k}^{\mathrm{h}} \mathrm{an} /$ & $/ \mathrm{k}^{\mathrm{h}} \mathrm{an} /$ \\
\hline 暗 & Yan Zi Le (颜子乐) & /an/ & /an/ \\
\hline 南 & Yan Zi Le (颜子乐) & $/ \mathrm{nan} /$ & /nan/ \\
\hline & \multicolumn{2}{|c|}{ Similarity } & $100 \%$ \\
\hline
\end{tabular}

Note. Version 1 is from the Shanghai Kunqu Opera Troupe. "Similarity" means the degree of similarity between singers' pronunciation of the eight Chinese characters and modern Mandarin sounds. Similarity = the number of Chinese characters pronounced as modern Mandarin sounds / Eight.

As Table 2 shows, about the eight Chinese characters, artists from the Shanghai Kunqu Opera Troupe choose the pronunciation of modern Mandarin, rather than the traditional phonetic system, in their singing of the traditional art Kunqu Opera, which is hard to be viewed as an optimistic phenomenon for the safeguarding of this ancient intangible heritage.

\subsection{Melody (Kunqiang)}

\subsubsection{Basic Rules about Melody in Kunqu Opera}

As a key factor that helps to shape Kunqu Opera, the melody of this art has its characteristics. In this research, 
comparative analyses of this factor between the two groups will be focused on musical notes, or to be exact, musical pitches changing.

Unlike modern Mandarin which has four tones, ancient Chinese, not later than the Qing dynasty (1636-1912), had eight tones particularly in southern China: Yin Ping (阴平), Yang Ping (阳平), Yin Shang (阴上), Yang Shang (阳上), Yin Qu (阴去), Yang Qu (阳去), Yin Ru (阴入) and Yang Ru (阳入). And musician Wei Liangfu (魏良辅 1489-1586), who was born in Ming dynasty and was considered as the father of Kunqu Opera, once pointed out in his article Nan Ci Yin Zheng (南词引正) that melody should change in accordance with lyrics' tones, which means the trends of musical pitches changing should be in line with the trends of lyrics' tonal values' changing (Luo, 2001).

Table 3. Trends of tonal values' changing of Chinese characters in Kunqu Opera

\begin{tabular}{lcccc}
\hline Tones & Yin Ping (阴平) & Yang Ping (阳平) & $\begin{array}{c}\text { Yin Shang (阴上) } \\
\text { Yang Shang (阳上) }\end{array}$ & $\begin{array}{c}\text { Yin Qu (阴去) } \\
\text { Yang Qu (阳去) }\end{array}$ \\
\hline Trends of Tonal Values' Changing & $\rightarrow$ & $\nearrow$ & $\searrow \nearrow$ & $\nearrow \searrow$
\end{tabular}

Note. This table is summarized from the relevant explanation of Xie (2019). Since characters of Yin $\mathrm{Ru}$ (阴入) and Yang Ru (阳入) are pronounced extremely shortly, the trends of their tonal values' changing are usually invisible.

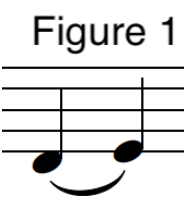

Figure 1. An example of melody which can express the tone of Yang Ping (阳平) in Kunqu Opera

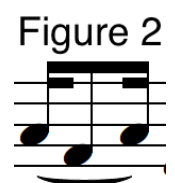

Figure 2. An example of melody which can express the tone of Yin Shang (阴上) and Yang Shang (阳上) in Kunqu Opera

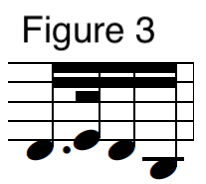

Figure 3. An example of melody which can express the tone of Yin Qu (阴去) and Yang Qu (阳去)in Kunqu Opera.

As illustrated in table 3, except Yin Ru (阴入) and Yang Ru (阳入), every tone has its own trends of tonal values' changing. And the trends of musical pitch's changing should observe tones' changing trends. For example, if a Chinese character belongs to Yin Shang (阴上) tone, when artists sing this character in Kunqu Opera, the corresponding musical pitch should also change like " $\searrow \nearrow$ ", just as Figure 2 shows. Sometimes one character's melody is too long and fluctuates heavily, if the front part of the melody is consistent with this character's tone, the melody can also be considered as complying with related rules of kunqiang, too. And in some other cases, one character's melody is too short to show its tone, if the next character's first note is helpful to show the tone, it's also acceptable. As for Yin Ru (阴入) and Yang Ru (阳入), they are pronounced extremely shortly. In order to express this feature, artists usually pause for a while after singing this tone, which means a rest on sheet music. In addition, as Yin Ping (阴平) tone is not so distinctive and always can be showed in a single note, this tone will not be discussed here.

\subsubsection{Comparison between the Two Groups on Melody}

The song Yi Jiang Feng (一江风) from the scene Open the Envelope (拆书), a part of the play The Story of the Western Chamber (西楼记) will be analyzed here to tell the inheritance of traditional rules by the Shanghai Kunqu Opera Troupe and the Shanghai Kunqu Study Society. The sheet music of the Shanghai Kunqu Opera 
Troupe can be found in their textbook Zhenfei Music Scripts (振飞曲谱), and the one of the Shanghai Kunqu Study Society is recorded in the book Collection of China's Opera Music: Jiangsu Province (中国戏曲音乐集 成・江苏卷). Among lyrics of the song, even though “Qiao (桥)" and “Shui (谁)" are Yang Ping (阳平) tones, which should be sung as “ $\nearrow$ " originally, since "Q" $\left(/ \mathrm{t} 6^{\mathrm{h}}\right)$ and "Sh" $(/ \mathrm{s} /)$ are voiced sounds (浊音), they could also be sung as " $\searrow$ " $(\mathrm{Yu}, 1982)$ and deemed following traditional rules.

Table 4. Comparison of melodies' observance of lyrics' tonal values' changing trends between Shanghai Kunqu Opera Troupe and Shanghai Kunqu Study Society in the song "Yi Jiang Feng" (一江风)

\begin{tabular}{cccccc}
\hline & $\begin{array}{c}\text { Yang Ping } \\
\text { (阳平) }\end{array}$ & $\begin{array}{c}\text { Yin Shang (阴上) } \\
\text { Yang Shang (阳上) }\end{array}$ & $\begin{array}{c}\text { Yin Qu (阴去) } \\
\text { Yang Qu (阳去) }\end{array}$ & $\begin{array}{c}\text { Yin Ru (阴入) Yang } \\
\text { Ru (阳入) }\end{array}$ & Total \\
\hline Characters & 16 & 8 & 12 & 2 & 38 \\
Version 1 & 14 & 4 & 11 & 0 & 29 \\
Observance 1 & $88 \%$ & $50 \%$ & $92 \%$ & $0 \%$ & $76 \%$ \\
Version 2 & 12 & 8 & 12 & 1 & 33 \\
Observance 2 & $75 \%$ & $100 \%$ & $100 \%$ & $50 \%$ & $87 \%$ \\
\hline
\end{tabular}

Note. Version 1 is from the Shanghai Kunqu Opera Troupe. Observance 1 means Version 1's observance of traditional rules. Observance $1=$ Version 1 / Characters. Version 2 is from the Shanghai Kunqu Study Society. Observance 2 means Version 2's observance of traditional rules. Observance $2=$ Version $2 /$ Characters.

As Table 4 shows, except in Yang Ping (阳平) tone, Observance 2 is higher than Observance 1, which means in terms of melody, the non-professional group, the Shanghai Kunqu Study Society, sung lyrics of the song Yi Jiang Feng (一江风) in line with traditional rules generally at a higher degree than the professional group, the Shanghai Kunqu Opera Troupe. The Shanghai Kunqu Study Society inherits more tradition of Kunqu Opera in the aspect of melody.

\subsection{Literary Form of Lyrics (Qupai Style)}

Differences in lyrics between the two groups are limited. The song Yi Jiang Feng (一江风) is taken as an example here. The following is its translation, and the Chinese version is from the book Jicheng Music Scripts (集成曲谱), which was first published in 1925 by The Commercial Press and widely considered as conforming to rules of qupai style then.

Table 5. Translation of Lyrics of the song Yi Jiang Feng (一江风)

\begin{tabular}{clc}
\hline Sentence & Chinese & English \\
\hline 1 & 意阑珊 & I feel very sad. \\
2 & 几度荒茶饭 & I even lost my appetite. \\
3 & 坐起惟长叹 & I could only sigh long and heavily. \\
4 & 记西楼 & I still remember that day in western chamber. \\
5 & 唤转声声 & She sang beautifully. \\
6 & 扶病而歌 & Even though she was ill. \\
7 & 遂把红丝绾 & We fell in love with each other. \\
8 & 蓝桥迟尺间 & We were so close. \\
9 & 蓝桥迟尺间 & We were so close. \\
10 & 谁知风浪翻 & How could we know there came a bolt from the blue suddenly! \\
11 & 常言好事多磨难 & Well, as the saying goes that the road to happiness is full of hardships. \\
\hline & &
\end{tabular}

In the Shanghai Kunqu Opera Troupe's version, only one character "Huan (唤)", the first one in sentence 5, is replaced by “Wan (宛)", the other lyrics are the same as Jicheng Music Scripts. And the same as "Huan (唤)", “Wan (宛)" is an oblique tone (反声) as well. In short, sentence 5 was revised according to traditional rules of qupai style.

In the Shanghai Kunqu Study Society's version, only one character "Ta (他)" is added at the beginning of sentence 6, the other contents are all the same as Jicheng Music Scripts. In Kunqu Opera, the adding of characters especially at the beginning of a sentence is acceptable for the purpose of expressing strong emotion (Yu, 2016). In other words, the singer changed sentence 6 based on traditional rules of qupai style.

To sum up, the two groups both inherit tradition about literary form of lyrics faithfully. 


\subsection{Performing Scenes}

Generally speaking, nowadays professional groups and non-professional ones have different preforming scenes.

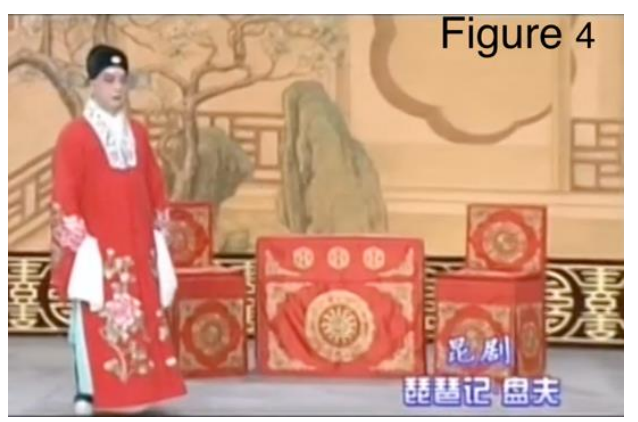

Figure 4. A general performing scene of professional Kunqu Opera groups, a screenshot of the Shanghai Kunqu Opera Troupe

Source: https://www.bilibili.com/video/BV1qK4y1U7M1/?spm_id_from=333.788.recommend_more_video.1

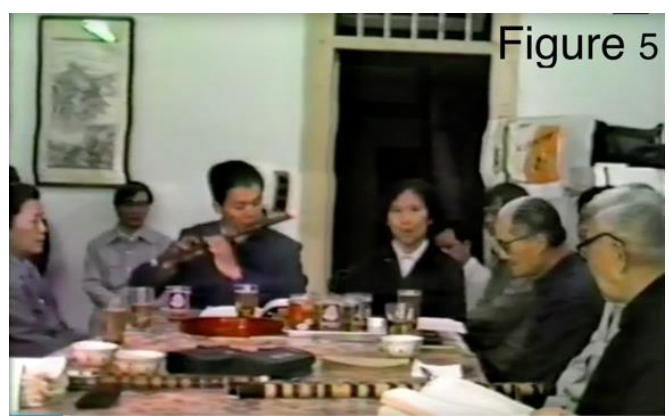

Figure 5. A general performing scene of non-professional Kunqu Opera groups, a screenshot of the Shanghai Kunqu Study Society

Source: https://www.bilibili.com/video/BV1a4411W7t6?from=search\&seid=7795543738567158244

As Figure 4 shows, professional Kunqu Opera groups, just like the Shanghai Kunqu Opera Troupe, usually perform on stage wearing costumes and make-up, while non-professional ones, as the Shanghai Kunqu Study Society, normally sit around a table to sing wearing everyday clothes without make-up like Figure 5 shows. Since Kunqu Opera was born as a kind of song at the very beginning, and the majority of practitioners then were scholars and musicians who sang it together around a table (Tang, 2017), non-professional groups at present still inherit the tradition loyally.

Thanks to the further critical literary and artistic creation of this art from scholar Liang Chenyu (梁辰鱼 1521-1594), who wrote the first opera work of the musical genre, the stage-performing art Kunqu Opera started to take shape. Professional Kunqu Opera troupes also came into being later and practice the art in the same way as professional ones do nowadays (Zhou, 2009). In short, current professional groups have also inherited traditional performing scenes till now.

\section{Conclusion}

Non-professional groups of intangible cultural heritage have long been considered as less important than professional ones when it comes to the inheritance of tradition. However, especially for highly complicated arts, that general perception may not be the truth. In this research, an elaborate comprehensive stage-performing art Kunqu Opera, which is more than 400 years old, was taken as an example to do some comparative analyses quantitatively and qualitatively between one professional group, the Shanghai Kunqu Opera Troupe, and one non-professional group, the Shanghai Kunqu Study Society, to re-recognize the importance of non-professional groups in the inheritance of tradition about pronunciation, melody, literary form of lyrics and performing scenes of this art.

For the pronunciation of Kunqu Opera, even though several dialects and some phonetic systems summarized by 
a few experts of this art are acceptable, there are traditionally acknowledged standards recorded in the book Yun Xue Li Zhu (韵学骊珠), which was written in Qing dynasty (1644-1912) by Suzhou local Shen Chenglin (沈乘 䜆). In this research, eight differently pronounced Chinese characters between the Shanghai Kunqu Opera Troupe and the Shanghai Kunqu Study Society in three songs-Yi Jiang Feng (一江风) from the play The Story of the Western Chamber (西楼记), Tai Shi Yin (太师引) from the play The Story of the Golden Bird (金雀记) and Yan Zi Le (颜子乐) from the play Peony Pavilion (牡丹亭)—were checked against the pronunciation in Yun Xue $\mathrm{Li}$ Zhu. As a result, the non-professional group pronounced 100\% in line with traditional standards. In contrast, the professional group pronounced $100 \%$ the same as modern Mandarin, which is obviously divergent from traditional standards. Therefore, it can be concluded that the non-professional group inherits more tradition in the pronunciation of Kunqu Opera than the professional one, which modernized its pronunciation.

About the melody (kunqiang) of this art, as the father of Kunqu Opera, Wei Liangfu (魏良辅 1489-1586), once pointed out that melody should change in accordance with lyrics' tones, which means musical pitch should fluctuate along with the changing of lyrics' tonal values. In this paper, melodies of the song Yi Jiang Feng (一江 风) in two versions, professional and non-professional ones, were examined to confirm their observance of traditional rules. Except for the tone Yang Ping (阳平), melodies in the non-professional version abide by traditional practice at a larger degree than the ones in the professional version: 100\% > 50\% in tones Yin Shang (阴上) and Yang Shang (阳上), 100\% > 92\% in tones Yin Qu (阴去) and Yang Qu (阳去), 50\% > 0\% in tones Yin Ru (阴入) and Yang Ru (阳入). Thus, the non-professional group, the Shanghai Kunqu Study Society inherits more tradition of Kunqu Opera in the aspect of melody than the professional group.

Speaking of the opera's literary form of lyrics (qupai style), the two versions both have minor changes compared to a version published in 1925 in Jicheng Music Scripts (集成曲谱), which was widely considered as conforming to rules of qupai style then. However, these changes all observe rules of the literary style not only in tones but also in sentence structures. In short, the Shanghai Kunqu Opera Troupe and the Shanghai Kunqu Study Society both inherit the tradition of qupai style faithfully.

As to performing scenes, since the art was born as a kind of song sung by amateurs around a table originally and developed into a stage-performing art later, both the professional group, the Shanghai Kunqu Opera Troupe, which generally practices the art on stage, and the non-professional group, the Shanghai Kunqu Study Society, which normally practice the art around a table, inherit the tradition of performing scenes well about this art.

In conclusion, different from general perceptions, non-professional groups of Kunqu Opera, like the Shanghai Kunqu Study Society, could inherit some traditional factors of this art, especially pronunciation and melody, to a larger degree than professional ones, like the Shanghai Kunqu Opera Troupe, thus non-professional groups' importance in the inheritance of this opera should be valued for the purpose of realizing more effective safeguarding of this intangible cultural heritage.

\section{Discussion}

In order to confirm the results of this research, more analyses based on a larger scale of Kunqu Opera works performed by more artists from the Shanghai Kunqu Opera Troupe and other professional groups, as well as more members from the Shanghai Kunqu Study Society and other non-professional groups are necessary in the future.

Additionally, according to interviews with members of the Shanghai Kunqu Study Society, no financial pressure could be a direct reason for them to be able to respect Kunqu Opera's tradition greatly. Since they don't have to cater to the mass-market and most modern audience, who are highly influenced by modernization and globalization, to earn a living, they could feel free to preserve the traditional artistic rules they cherish heavily by studying, practicing as well as imparting them to other amateurs seriously. And further researches need to deepen current understandings about why (direct and indirect reasons) and how non-professional Kunqu Opera groups could inherit some traditional factors more faithfully than professional ones, which can be enlightening for professional ones to improve their inheritance of this heritage.

What's more, other highly complicated performing arts, like Peking Opera and Sichuan Opera for instance, also need to be analyzed on the inheritance between professional and non-professional groups in order to enhance current safeguarding practices.

As for other performing arts as well as more intangible cultural heritages, even though not every heritage has its own non-professional groups, their existence should be paid attention to seriously. And in order to safeguard intangible cultural heritages more effectively, these groups' inheritance and influence on living heritages are worth studying carefully. 


\section{Acknowledgements}

I am grateful for the guidance and support from Mr. Pu Hainie, Dr. Wang Xin, and Ms. Li Si during this research being conducted.

\section{Conflict of Interests}

The authors declare that there is no conflict of interests regarding the publication of this paper.

\section{References}

Cai, Z. R. (1992). Thinking on Rejuvenating Kunqu Opera. Chinese Theatre, (5), 36-38. Retrieved from https://gb.global.cnki.net/KCMS/detail/detail.aspx?dbcode=CJFQ\&dbname=CJFD9093\&filename=XIJU19 9205019\&v=MTAxNDRIN0t4Rj1QTXFvOUViWVI4ZVgxTHV4WVM3RGgxVDNxVHJXTTFGckNVUj d1ZVorUnZGeTNtVkw3T1BTVEI=

Collection of China's Opera Music Editing Committee. (1992). Collection of. China's Opera Music: Jiangsu Province. Xinhua Bookstore.

Institute of Music, Academy of Literature and Art, Ministry of Culture. (1981). An Anthology of Ancient Chinese Music Theories. People's Music Publishing House.

Liu, Z. E., Li, Y., \& Shang, J. Y. (2017). Report on Problems, Reasons and Strategies of Civil Groups of Kunqu Opera. Chinese Theatre, 56-57. https://gb.global.cnki.net/KCMS/detail/detail.aspx?dbcode=CJFQ\&dbname=CJFDLAST2017\&filename $=X$ IJU201704027\&v=MDAwNDFyQ1VSN3VIWitSdkZ5M2tVTHpBUFNUQmU3RzRIOWJNcTQ5SFk0Ujh IWDFMdXhZUzdEaDFUM3FUcldNMUY=

Luo D. (2001). Ci Yue Qu Chang. People's Music Publishing House.

National Bureau of Statistics. (1982). Bulletin of the Third National Census. Retrieved from http://www.stats.gov.cn/tjsj/tjgb/rkpcgb/qgrkpcgb/200204/t20020404_30318.html

Shen, C. L. (2006). Yun Xue Li Zhu. Zhonghua Book Company.

Sun, X. L. (2012). A Study on the Kun Opera Protection Organizations-Based on a survey in Suzhou (Master's thesis, Soochow University, Jiangsu, China). https://kns.cnki.net/kcms/detail/detail.aspx?dbcode=CMFD\&dbname=CMFD2012\&filename=1012390586. nh\&v=1SGA\%25mmd2Bym6L7blYJk7phpaQ11I0mYfD6gGCvHvtAXtaQJwrRMmaPOwnIXwEUupV22 $\mathrm{Q}$

Tang, Z. H. (2015). On the Current Situation of Kunqu Opera Society. Journal of Jilin University of Arts, 125(2), 46-49. https://doi.org/10.13867/j.cnki.1674-5442.2015.02.12

Tang, Z. H. (2017). Research on Qinggong of Kunqu Opera (Doctoral dissertation, Fujian Normal University, Fujian, China). https://doi.org/10.27019/d.cnki.gfjsu.2017.000035

Wang, J. L., \& Liu, F. L. (1925). Jicheng Music Scripts. The Commercial Press.

Wang, X. (2013). The Inheritance of Kunqu Opera during Republic of China Period in Tianjin City. Songs Bimonthly,

84-87. https://gb.global.cnki.net/KCMS/detail/detail.aspx?dbcode=CJFQ\&dbname=CJFD2013\&filename=GHAI2 01305022\&v=MDAwNDFyQ1VSN3VlWitSdkZ5M21WcnpCSW1YS1o3RzRIOUxNcW85SFpvUjhlWDF MdXhZUzdEaDFUM3FUcldNMUY=

Xiang, Y. C. (1963). Qu Yun Yi Tong. Zhonghua Book Company.

Xie, Y. F. (2019). On the Accent of Chinese Character and It's Cohesive Accent In the Song of North-South Qu. $\begin{array}{llllr}\text { Hundred } \quad \text { Schools } & \text { in }\end{array}$ https://gb.global.cnki.net/KCMS/detail/detail.aspx?dbcode=CJFQ\&dbname=CJFDLAST2019\&filename=Y SBJ201902015\&v=MDAwNDFyQ1VSN3VlWitSdkZ5M21XNzdCUEQ3SlpMRzRIOWpNclk5RV1ZUjhl WDFMdXhZUzdEaDFUM3FUcldNMUY=

Yu, M. L. (2016). Rules about Adding Characters in Kunqu Opera (Part 1). Shanghai Theatre, (9), 32-33, https://doi.org/10.14179/j.cnki.shxj.2016.09.011

Yu, Z. F. (1982). Zhenfei Music Scripts. Shanghai Literature and Art Publishing House.

Yuan, L. (2007). Research on Problems of the Protection of Intangible Cultural Heritage Bearers. Exploration $\begin{array}{llll}\text { and } & \text { Free } & \text { 6iews, } & \text { (7), }\end{array}$ 
https://gb.global.cnki.net/KCMS/detail/detail.aspx?dbcode=CJFQ\&dbname=CJFD2007\&filename=TSZM2 00707021\&v=MDYzMzRxVHJXTTFGckNVUjd1ZVorUnZGeTNsVUxyTE1UN1JZN0c0SHRiTXFJOUh aWVI4ZVgxTHV4WVM3RGgxVDM=

Zhang, B. (2007). Research on the Protection of Cultural Space of Intangible Cultural Heritage. Qinghai Social Sciences, (1), 33-36 \& 41. https://doi.org/10.14154/j.cnki.qss.2007.01.009

Zhao, R., \& Uekita, Y. (2020). Factor-Based Quantitative Comparison Analysis of the Inheritance of Intangible Cultural Heritage: A Case Study of Kunqu Opera between Chinese Mainland and Taiwan. Asian Culture and History, 12(2), 23-32. https://doi.org/10.5539/ach.v12n2p23

Zhou, D. 周丹 (2009). A Comparison-study of Singing Kunqu without Staging and Singing Kunqu with Staging (Master's thesis, Communication University of China, Beijing, China). https://kns.cnki.net/kcms/detail/detail.aspx?dbcode=CMFD\&dbname=CMFD2010\&filename=2009226959. nh\&v=ug\%25mmd2B4m2zPFd2DeUdsgH1pEajpZiQZvjtjwTVzX\%25mmd2FiYII1Qxg6Esu1eHCQcd8Z KscIV

Zhu, Q. (2007). Research on Colleges Art Education's Inheritance and Creation of Intangible Cultural Heritage. Art Education, $\quad$ 36-37. https://gb.global.cnki.net/KCMS/detail/detail.aspx?dbcode=CJFQ\&dbname=CJFD2007\&filename=YSJY2 00710023\&v=MDQ2NThNMUZyQ1VSN3VIWitSdkZ5M2xWNy9CUEQ3QmQ3RzRIdGJOcjQ5SFo0Ujh lWDFMdXhZUzdEaDFUM3FUclc=

\section{Copyrights}

Copyright for this article is retained by the author(s), with first publication rights granted to the journal.

This is an open-access article distributed under the terms and conditions of the Creative Commons Attribution license (http://creativecommons.org/licenses/by/4.0/). 